引用格式: 牛海鹏, 李聪聪. 利益相关者视角下内江市农村土地承包经营权退出绩效评价 [J]. 资源科学, 2019,41(2) : 219-232. [Niu H P, Li C C. Performance evaluation of rural land contract management right exit in Central District of Neijiang City from the perspective of stakeholders[J]. Resources Science,2019,41(2):219-232.] DOI :10.18402/resci.2019.02.02

\title{
利益相关者视角下内江市农村土地承包经营权 退出绩效评价
}

\author{
牛海鹏 ${ }^{1,2}$, 李聪聪 ${ }^{1}$ \\ (1. 河南理工大学测绘与国土信息工程学院, 焦作 454000; \\ 2. 河南理工大学土地经济与城乡发展研究中心, 焦作 454000)
}

\begin{abstract}
摘 要: 农村土地承包经营权退出涉及重大利益关系调整和农村土地制度的发展和完善, 开展土地承包经营 权退出绩效评估有利于反映退出政策的成效和不足, 为退出模式的选择和优化提供理论借鉴。本文基于利益相关 者视角, 提出了农村土地承包经营权退出绩效概念, 构建了农村土地承包经营权退出绩效三棱柱评价模型, 并运用 综合指数法科学评价了内江市市中区农村土地承包经营权退出换现金、换股份和换保障模式的单项绩效和综合绩 效。结果表明: (1) 基于利益相关者视角的绩效三棱柱评价模型适用于农村土地承包经营权退出绩效评价, 其单项 绩效和综合绩效能够反映土地承包经营权退出的成效及不足; (2)不同退出模式的单项绩效水平和综合绩效水平具 有显著的差异性,退出换现金模式除了基于农村集体经济组织视角的绩效值高于退出换股份模式外,其他视角(农 户和农业经营组织) 及综合绩效值均低于退出换股份模式,退出换保障模式绩效最差; (3)依据不同退出模式的绩效 水平差异, 在相互借鉴的基础上取长补短、因地制宜地探寻理想的优化方案对于推进农村土地承包经营权有序退 出具有重要意义。
\end{abstract}

关键词: 农村; 土地承包经营权; 利益相关者; 退出绩效; 绩效三棱柱模型; 内江市

DOI :10.18402/resci.2019.02.02

\section{1 引言}

农村土地承包经营权退出是土地使用制度改 革的推进和市场经济体制下生产要素优化配置与 合理流动的必然 ${ }^{[1]}$, 是实现农业现代化、城镇化和工 业化协调推进的关键, 是解决土地承包经营权流转 期望与现实之间存在差距以及新的“逆向”不公平 问题的重要手段。2014年11月,农业部会同农村改 革试验区工作联席会议成员单位下发的《关于第二 批农村改革试验区和实验任务的批复 $\rangle^{[2]}$, 正式将农 村土地承包经营权退出纳人试点任务, 批准重庆市 梁平县、四川省成都市、四川省内江市市中区、贵州 省遵义市湄潭县等作为该项任务的试点区域。 2015 年国务院办公厅印发的《关于加快转变农业发
展方式的意见 $\rangle^{[3]}$ 、中共中央办公厅国务院办公厅印 发的《深化农村改革综合性实施方案》和 2016 年国 务院印发的《全国农业现代化规划 (2016-2020 年) 》 ${ }^{[4]}$,均提出在农村改革试验区或在有条件的地 方稳妥开展农村土地承包经营权有偿退出试点。 以上相关文件的颁布和实施为农村土地承包经营 权退出提供了制度保障和政策支撑。

目前, 国内学者主要针对农村土地承包经营权 退出的必要性 ${ }^{[5,6]}$ 、退出形式 ${ }^{[7,8]}$ 、退出现状 ${ }^{[9,10]}$ 、退出困 境 ${ }^{[1,12]}$ 、退出机制构建 ${ }^{[13,14]}$ 、退出影响因素 ${ }^{[15-17]}$ 等方面 展开了相应的研究和探讨, 关于农村土地承包经营 权退出绩效定量评估方面的研究鲜有涉及。由于 农村土地承包经营权退出在本质上属于农村土地

收稿日期: 2018-08-15 修订日期: 2018-09-10

基金项目:国家社会科学基金项目(18BJY126)。

作者简介: 牛海鹏, 男, 河南南阳市人, 博士, 教授, 博士生导师, 主要从事土地资源管理方面的教学与科研工作。E-mail: niuhaipeng@126.com 
流转的进一步深化和改革, 因此, 农村土地流转绩 效评价研究对于开展农村土地承包经营权退出绩 效评估具有较强的借鉴价值。在农村土地流转绩 效评价方面,程飞等、周菁等、王雅瑜等从农户视角 出发, 基于层次分析法与熵权法对土地流转绩效各 评价指标进行组合赋权, 并运用综合指数法评价了 农村土地流转各模式的经济、社会、生态以及综合 绩效 ${ }^{[18-20]}$ 。许亚敏等通过投影寻踪技术对比分析了 不同土地流转模式及不同土地流转案例的经济、社 会和环境绩效 ${ }^{[2]}$ 。王立敏等从组织能力、运营能力、 发展能力以及社会影响能力 4 个维度构建绩效评价 指标体系, 运用层次分析法和功效系数法分别确定 了指标权重和指标值, 并进一步通过线性加权法测 算了潍坊市农地流转中介组织的总体运行情况 ${ }^{[2]}$ 。 综上所述, 现有研究多是对微观视角下某一利益相 关者主体的绩效评价, 而基于多利益相关者视角对 不同流转模式绩效差异及模式优化的系统研究相 对较少。此外, 现有绩效评价多集中在经济、社会、 生态的结果绩效评价阶段, 尚缺乏对行为绩效和综 合绩效的实证评估。但有学者李文彦等在综合考 虑征地过程中各利益相关主体的基础上, 从土地征 收利益相关者满意、利益相关者贡献、战略、能力和 流程 5 个方面构建了贵州省农村集体土地征收绩效 三棱柱评价指标体系, 并采用模糊综合评价法对三 穗县土地征收绩效进行了综合评价 ${ }^{[23]}$, 为本文绩效评 估模型的构建提供了思路。

基于此,本文选取四川省内江市市中区为实证 研究区域, 从农户、农村集体经济组织、农业经营组 织 3 个利益相关者视角出发, 构建基于行为绩效和 结果绩效综合表征的农村土地承包经营权退出绩 效三棱柱评价模型, 对比分析内江市市中区农村土 地承包经营权退出换现金、换股份和换保障模式的 单项绩效水平和综合绩效水平差异, 以期为农村土 地承包经营权退出绩效评价体系的构建和现有实 践模式的路径优化提供理论基础和现实依据。

\section{2 研究区概况、理论方法与数据来源}

\section{1 研究区概况}

内江市市中区地处四川盆地川中丘陵地带中 南部, 沱江中下游右岸, 连接成渝经济圈, 融人川南 城市群, 是内江市政治、经济、商贸、交通和文化中 心。全区土地面积 3.86 万 $\mathrm{hm}^{2}$, 户籍总人口 54 万, 辖
13 镇和 7 个街道办事处, 存在着人多地少、地块较为 分散、劳动力大量外出、耕地撂荒、村民增收乏力等 问题。2014年11月,市中区被批复为全国第二批农 村改革试验区, 承担着农村土地承包经营权退出试 点任务。市中区紧抓这次改革机遇, 创新性地实践 了退地换现金、换股份、换保障的“三换”模式。在 中国改革 2016年会暨创新驱动高层研讨会上,市中 区土地承包经营权退出 “三换”模式人选 2016 年中 国改革十大案例。

\section{2 理论方法}

\subsection{1 绩效三棱柱概念模型}

农村土地承包经营权退出作为一项深化农村 土地改革的制度安排,涉及重大利益关系的调整。 评估其核心利益相关者(农户、农村集体经济组织、 农业经营组织)在农村土地承包经营权退出前决 策、退出中行为效率以及退出后效果的绩效水平, 是考察农村土地承包经营权退出政策实施成效的 重要环节。结合已有的研究成果 ${ }^{[23]}$ 可以发现,绩效 三棱柱模型是一种全面且关注所有核心利益相关 者利益诉求的绩效模型。该模型不仅适用于事后 绩效测量,还关注事前决策和事中控制行为的绩效 评估,是一种科学又全面的评估模型。另外,该模 型具有较大的灵活性,可同时将一个或多个利益相 关者放在一个理论体系中进行考察, 满足本文对农 村土地承包经营权退出进行单项绩效评价和综合 绩效评价的需要。因此,绩效三棱柱模型适合用来 构建农村土地承包经营权退出绩效评价指标体系。

绩效三棱柱模型 (Performance Prism) 是由克兰 菲尔德学院教授 Andy Neely 与安达信咨询公司为 克服传统绩效评价方法的缺点, 实现多角度评价而 联合开发的三维绩效框架模型 ${ }^{[23]}$ 。它用三棱柱的 5 个面分别代表组织绩效存在内在因果关系的 5 个关 键要素,具体包括:

(1)利益相关者满意: 明确组织的主要利益相 关者及其需求和愿望是什么;

(2)利益相关者贡献: 组织需要从利益相关者 那里得到什么;

(3)战略: 组织应该制定何种战略来满足利益 相关者需求的同时也满足组织自己的需求;

(4) 流程: 组织需要具备什么样的流程才能顺 利执行战略; 
(5) 能力: 组织需要具备什么样的能力来运作 这些流程。

结合绩效三棱柱概念模型, 本文将农村土地承 包经营权退出绩效定义为: 农村土地承包经营权退 出的核心利益相关者(农户、农村集体经济组织和 农业经营组织)在退出前决策、退出中行为效率和 退出后效果方面的综合表征。其中,利益相关者满 意和利益相关者贡献领域反映退出后结果绩效的 内涵, 战略领域反映退出前决策时行为绩效的内 涵, 能力和流程领域反映退出过程中行为绩效的 内涵。

\subsection{2 绩效三棱柱指标体系构建}

本文在现有研究成果 ${ }^{[18,23]}$ 的基础上,结合内江 市市中区农村土地承包经营权退出的实际情况, 从 利益相关者满意、利益相关者贡献、战略、能力和流 程 5 个领域、3个利益相关者视角(农户、农村集体经 济组织、农业经营组织) 出发构建了农村土地承包 经营权退出绩效三棱柱评价指标体系, 具体见表 1 。

(1)利益相关者满意。农村土地承包经营权退 出是一项涉及重大利益关系调整的复杂项目,其核 心利益相关者(农户、农村集体经济组织和农业经 营组织) 的主观感受一一即满意度评价, 是农村土 地承包经营权退出绩效评价的重点。其中, 农户满 意度主要体现在退出意愿、退出模式和退出补偿方 面, 农村集体经济组织满意度主要体现在实施土地 承包经营权退出后村容村貌、经济实力改变状况以 及农户配合程度方面, 农业经营组织满意度主要体 现在规模经营目标的实现率以及经营退出土地产 出率方面。因此, 文中选取“农户退出土地承包经 营权的意愿率、农户对该退出补偿标准的满意率、 农户对该退出模式的满意率、农户对退出工作的配 合程度、村集体负责人员对退出工作的满意率、农 业组织规模经营目标的实现率以及对退出工作的 满意率”7 个指标反映利益相关者的满意度状况。

(2)利益相关者贡献。农村土地承包经营权退 出是为增加农户收人、壮大村集体经济、实现土地 规模经营而提出的战略构想。因此, 文中以“农户 人均纯收人变化率、农户恩格尔系数变化率、村集 体收人变化率、村集体贫困人口变化率、土地撂荒 面积变化率、单位土地产出变化率、单位土地机械 使用变化率”7 项指标表征农村土地承包经营权退
出的结果绩效。

(3)战略。为满足利益相关者需求的同时又实 现实施农村土地承包经营权退出的目标, 需要制定 相应的战略来满足需求。首先,农户对退出政策的 充分认识、对退出风险的零判定 (指农户认为退出 土地承包经营权不存在风(险) 以及对退出政策的支 持是实现土地承包经营权顺利退出的关键; 就农村 集体经济组织来说, 实施退出模式的出发点是保护 退出农户的切身利益,减少农户关于承包地的产权 纠纷,引导农户有序退出土地承包经营权, 从而实 现农村土地规模经营; 对于农业经营组织而言, 合 理安排生产要素投人, 以最小的投人获取最大的利 益是其制定战略的出发点。考虑数据的合理性及 可获取性,以“农户对退出政策的认识程度、农户对 退出风险的判定、土地承包经营权退出的公众支持 率、村集体土地规模经营实现率、退出农户产权纠 纷变化率、政府投人资金占退出补偿金的比重、单 位土地劳动力投人变化率、单位土地科技投人变化 率”8项指标表征退出前决策的行为绩效。

(4) 能力。根据利益相关者的利益诉求及战略 目标要求,农户需具备维权意识、抗风险能力和再 就业能力,村集体具备按时按量发放退出补偿金以 及为农户购买养老保险的能力,农业经营组织需要 有一定的盈利能力来保障退出补偿金的足额发 放。因此,本文选取“退出农户维护自身权利的水 平、退出农户风险规避能力、退出农户接受职业培 训的比率、退出补偿金拨付及时度、退出农户在农 业组织中实现就业的比率、单位土地农业组织利润 变化率、退出补偿金占农业组织利润的比重” 7 项指 标表征退出过程中行为效率绩效。

(5)流程。流程主要包括退出前是否进行政策 宣传,决策程序是否科学、民主、高效,是否让农户 参与退出补偿决策, 是否尊重农户意愿, 退出过程 是否公开,农业经营组织是否让就业农户参与到生 产决策中,盈利信息是否公开等方面。考虑数据的 科学性和可获取性, 文中选取“农户对退出程序的 认识程度、农户决策参与度、退出程序合法性、退出 过程公开性、农户生产过程参与度、信息共享度” 6 项指标表征退出过程中的行为绩效。

\subsection{3 评价方法}

鉴于农村土地承包经营权退出绩效评价涉及 


\section{表 1 农村土地经营权退出绩效评价指标体系}

Table 1 Performance evaluation index system for the exit of rural land contract management right

\begin{tabular}{|c|c|c|c|}
\hline 目标层 & 准则层 & 指标层 & 指标含义 \\
\hline 农村土地 & 利益相关 & 农户退出土地承包经营权的意愿率 $C 1$ & 愿意退出的农户样本数/农户样本总数 \\
\hline 承包经营 & 者满意 $B 1$ & 农户对该退出补偿标准的满意率 $C 2$ & 对该退出补偿标准满意的农户样本数/农户样本总数 \\
\hline 权退出绩 & & 农户对该退出模式的满意率 $C 3$ & 对该退出模式满意的农户样本数/农户样本总数 \\
\hline \multirow[t]{32}{*}{ 效评价 $A 1$} & & 农户对退出工作的配合程度 $C 4$ & 愿意配合村集体完成退出工作的农户样本数/农户样本总数 \\
\hline & & 村集体负责人员对退出工作的满意率 $C 5$ & 对退出工作满意的村集体负责人员样本数/村集体负责人员样本总数 \\
\hline & & 农业组织规模经营目标的实现率 $C 6$ & 现有土地规模/预期土地规模 \\
\hline & & 农业组织对退出工作的满意率 $C 7$ & 对退出工作满意的农业组织负责人员样本数/农业组织负责人员样本总数 \\
\hline & 利益相关 & 农户人均纯收人变化率 $C 8$ & 退出后农户人均纯收人增加量/退出前农户人均纯收人 \\
\hline & 者贡献 $B 2$ & 农户恩格尔系数变化率 $C 9$ & 退出后农户恩格尔系数减少量/退出前农户恩格尔系数 \\
\hline & & 村集体收入变化率 $C 10$ & 退出后村集体收人增加量/退出前村集体收人 \\
\hline & & 村集体贫困人口变化率 $C 11$ & 退出后贫困人口减少数/退出前贫困人口数 \\
\hline & & 土地撂荒面积变化率 $C 12$ & 退出后土地撂荒面积减少量/退出前土地撂荒面积 \\
\hline & & 单位土地产出变化率 $C 13$ & 退出后单位土地产值增加额/退出前单位土地产值 \\
\hline & & 单位土地机械使用变化率 $C 14$ & 退出后单位土地机械使用增加额/退出前单位土地机械使用额 \\
\hline & 战略 $B 3$ & 农户对退出政策的认识程度 $C 15$ & 了解退出政策的农户样本数/农户样本总数 \\
\hline & & 农户对退出风险的判定 $C 16$ & 认为退出不存在风险的农户样本数/农户样本总数 \\
\hline & & 土地承包经营权退出的公众支持率 $C 17$ & 支持退出的农户样本数/农户样本总数 \\
\hline & & 村集体土地规模经营实现率 $C 18$ & 村集体对退出土地实现规模经营的面积/村集体土地总面积 \\
\hline & & 退出农户产权纠纷变化率 $C 19$ & 退出后发生产权纠纷减少次数/退出前产权纠纷发生次数 \\
\hline & & 政府投人资金占退出补偿金的比重 C20 & 政府投人资金额/退出补偿金总额 \\
\hline & & 单位土地劳动力投人变化率 $C 21$ & 退出后单位土地劳动力投人增加额/退出前单位土地劳动力投人量 \\
\hline & & 单位土地科技投人变化率 $C 22$ & 退出后单位土地科技投入增加额/退出前单位土地科技投入额 \\
\hline & 能力 $B 4$ & 退出农户维护自身权利的水平 $C 23$ & 能够维护自身权利的农户样本数/农户样本总数 \\
\hline & & 退出农户风险规避能力 $C 24$ & 有风险规避能力的农户样本数/认为退出存在风险的农户样本总数 \\
\hline & & 退出农户在农业组织中实现就业的比率 $C 25$ & 在农业组织实现就业的农户样本数/农户样本总数 \\
\hline & & 退出补偿金拨付及时度 $C 26$ & 能按时按量收到退出补偿金的农户样本数/农户样本总数 \\
\hline & & 退出农户养老保险覆盖变化率 $C 27$ & 退出后村集体养老保险覆盖率增加量/退出前村集体养老保险覆盖率 \\
\hline & & 单位土地农业组织利润变化率 $C 28$ & 退出后单位土地利润增加额/退出前单位土地利润 \\
\hline & & 退出补偿金占农业组织利润的比重 $C 29$ & 农业组织支付退出补偿金/农业组织利润 \\
\hline & 流程 $B 5$ & 农户对退出程序的认识程度 C30 & 熟悉退出程序的农户样本数/农户样本总数 \\
\hline & & 农户决策参与度 $C 31$ & 参与退出补偿决策的农户样本数/农户样本总数 \\
\hline & & 退出程序合法性 C32 & 自愿退出农户样本数/农户样本总数 \\
\hline & & 退出过程公开性 $C 33$ & 认为退出过程公开的农户样本数/农户样本总数 \\
\hline & & 农户生产过程参与度 $C 34$ & $\begin{array}{l}\text { 参与农业组织生产决策的就业农户样本数/在农业组织中实现就业的农 } \\
\text { 户样本总数 }\end{array}$ \\
\hline & & 信息共享度 $C 35$ & 农业组织信息的就业农户样本数/农业组织中实现就业的农户样本总数 \\
\hline
\end{tabular}

注: (1) 本文将机械使用量、劳动力投人量和科技投人量进行了货币化处理; (2) 鉴于农村集体经济组织和农业经营组织样本量少以及从 农户视角获取数据更具真实性的原因,村集体和农业经营组织的部分指标数据是通过农户视角来反映; (3)农户、农村集体经济组织以及农业 经营组织视角的指标体系分别从以上综合指标体系中抽取出来。

的主体多、范围广、相关数据难以获得的特点, 基于 层次分析法和熵权法优点和适用范围的考虑, 本文 采用 1 9标度值为判断标准的层次分析法对综合绩 效评价指标进行赋权, 通过建立递阶层次结构、构
造两两比较判断矩阵及层次单排序, 经一致性检验 求得权重; 同时, 采用熵权法对分视角单一退出模 式绩效评价指标进行赋权。摘权法是一种在综合 考虑各评价指标提供信息量的基础上,根据各项评 
价指标值的差异程度来确定权重的客观赋权法 ${ }^{[24]}$ 。 用熵来确定权重时,若指标所提供的有效信息量越 大,熵值越小,该指标权重就越大; 反之, 熵值越大,该 指标权重就越小 ${ }^{[25]}$ 。熵权法赋权的基本步骤如下 ${ }^{[26]}$ 。

(1)数据标准化处理。为了消除评价指标单位 和量纲差异性,本文采取极大值标准化法对原始指 标数据进行标准化处理, 得到标准化决策矩阵 $Y$ (公 式(3))。由于本文构建的农村土地承包经营权退 出绩效评价指标中有正、负向指标, 因此, 其计算公 式如下：

正向指标:

$$
y_{i j}=\frac{x_{i j}-x_{\min }}{x_{\text {max }}-x_{\min }} \quad i=1,2, \cdots, m ; j=1,2, \cdots, n
$$

负向指标:

$$
\begin{aligned}
& y_{i j}=\frac{x_{\text {max }}-x_{i j}}{x_{\text {max }}-x_{\text {min }}} \quad i=1,2, \cdots, m ; j=1,2, \cdots, n \\
& Y=\left|y_{i j}\right|_{m \times n}
\end{aligned}
$$

式中: $y_{i j}$ 为标准化处理后第 $i$ 个评价对象对第 $j$ 个 评价指标的值; $x_{i j}$ 为第 $i$ 个评价对象对第 $j$ 项评价 指标的实际值; $x_{\text {max }}$ 是标准化处理前第 $i$ 个评价对 象第 $j$ 个评价指标的最大值; $x_{\text {min }}$ 是标准化处理前 第 $i$ 个评价对象第 $j$ 个评价指标的最小值; $m$ 为评 价对象个数; $n$ 为评价指标个数。

(2) 确定各评价指标因子的信息熵 $e_{j}$, 公式如 下：

$$
\begin{aligned}
& e_{j}=-\sum_{i=1}^{m} p_{i j} \ln p_{i j} / \ln m \\
& p_{i j}=y_{i j} / \sum_{i=1}^{m} y_{i j}
\end{aligned}
$$

式中: $p_{i j}$ 为标准化后的第 $i$ 个评价对象第 $j$ 项指标 $y_{i j}$ 在第 $j$ 项评价指标中所占的比重。

(3) 确定各评价指标因子的权重 $w_{j}$ :

$$
w_{j}=\left(1-e_{j}\right) / \sum_{j=1}^{n}\left(1-e_{j}\right)
$$

在综合比较模糊综合评价法、物元分析法、 DEA 数据包络分析法等常用绩效评价方法优缺点 及适用范围的基础上, 考虑本文所选取的指标多但 均可获得并量化, 故选用操作简单、易推广的综合 指数法来评价农村土地承包经营权退出绩效。计 算公式 ${ }^{[27]}$ 如下：

$$
H=\sum_{i=1}^{n} H_{i} W_{i}
$$

式中: $H$ 为农村土地承包经营权退出绩效指数; $H_{i}$ 为通过绩效指标体系 (表 1)中的计算公式求取的第 $i$ 项指标初始绩效值; $W_{i}$ 为第 $i$ 项指标在评价指标 体系中的权重; $n$ 为评价指标的个数。

\section{3 数据来源与样本特征}

截至调查日期,四川省内江市市中区仅在龙门 镇龙门村开展退出换现金试点,在永安镇大庄村、 七里冲村和太平寺村试点退出换股份, 在永安镇下 元村开展退出换保障的试点工作。本文研究所用 数据均来源于课题组 2018 年 4 月 2 日至 4 月 12 日对 内江市市中区已实施土地承包经营权退出换现金、 换股份、换保障“三换”模式的试点村开展的问卷调 查。问卷调查均采取随机抽样调查法, 调查对象为 农村集体经济组织、农业经营组织和参与土地承包 经营权退出的农户。在农村集体经济组织的问卷 调查中, 主要以试点村的重要村集体领导干部 (书 记、村长等)为调查样本。在农业经营组织的问卷 调查中, 主要以试点村引进的农业经营组织为调查 样本。在农户的问卷调查中, 选取试点村中多于一 半的退出农户作为样本农户。本文研究所开展的 实地调查均采用问卷调查与半结构访谈相结合的 形式, 由调研人员与调研对象面对面访谈,并在调 查结束后对调查问卷进行审核和完善, 因此,本次 实地调查共发放的 265 份农户类问卷、18 份农村集 体经济组织类问卷和 3 份农业经营组织类问卷均有 效回收, 问卷有效率达到 $100 \%$ 。调查问卷的样本 分布情况如表 2 所示。

农村土地承包经营权退出农户的基本信息如 表 3 所示, 从受访者的个人信息来看, 3 种退出模式 的受访农户都是户主身份的男性居多; 退出换现 金、换股份模式的受访农户以中年为主, 分别占其 样本总数的 $65.69 \%$ 和 $62.82 \%$, 换保障的受访农户以 老年为主, 占样本总数的 $42.86 \% ; 3$ 种退出模式的绝 大多数受访农户文化程度为初中及以下,小学文化 程度分别占其样本总数的 $48.04 \%$ 、 $44.87 \%$ 和 $57.14 \%$; 退出前 3 种退出模式的农户职业多以务农 为主,退出后退出换现金、换股份农户的职业以务 工为主, 分别占其样本总数的 $65.69 \%$ 和 $61.54 \%$, 退 出换保障的务工农户所占比重较低, 仅占样本总数 
表 2 农村土地承包经营权退出问卷调查样本统计

Table 2 Sample statistics of rural land contractual management rights exit questionnaire

\begin{tabular}{|c|c|c|c|c|c|c|c|c|c|c|}
\hline \multirow{2}{*}{$\begin{array}{l}\text { 退出 } \\
\text { 模式 }\end{array}$} & \multirow{2}{*}{$\begin{array}{l}\text { 研究 } \\
\text { 区域 }\end{array}$} & \multirow{2}{*}{$\begin{array}{l}\text { 退出 } \\
\text { 类型 }\end{array}$} & \multicolumn{4}{|c|}{ 农户类 } & \multicolumn{2}{|c|}{ 农村集体经济组织类 } & \multicolumn{2}{|c|}{ 农业经营组织类 } \\
\hline & & & 频数/份 & 比重 $/ \%$ & 参与退出农户数/户 & 比重/\% & 频数/份 & 比重/\% & 频数/份 & 比重 $/ \%$ \\
\hline \multirow[t]{4}{*}{ 退出换现金 } & 龙门村 & 永久 & 1 & 0.98 & 2 & 50.00 & - & - & - & - \\
\hline & & 长期 & 48 & 47.06 & 53 & 90.57 & - & - & - & - \\
\hline & & 短期 & 53 & 51.96 & 240 & 22.08 & - & - & - & - \\
\hline & 合计 & & 102 & 100.00 & 295 & 34.58 & 4 & 22.22 & 2 & 66.67 \\
\hline \multirow[t]{4}{*}{ 退出换股份 } & 大庄村 & 长期 & 36 & 23.08 & 230 & 15.65 & 3 & 16.67 & - & - \\
\hline & 七里冲 & & 54 & 34.61 & 250 & 21.60 & 4 & 22.22 & - & - \\
\hline & 太平寺 & & 66 & 42.31 & 250 & 26.40 & 3 & 16.67 & - & - \\
\hline & 合计 & & 156 & 100.00 & 730 & 21.37 & 10 & 55.56 & 1 & 33.33 \\
\hline \multirow[t]{2}{*}{ 退出换保障 } & 下元村 & 永久 & 7 & - & 12 & 58.33 & 4 & 22.22 & - & - \\
\hline & 总计 & & 265 & - & 1037 & 25.55 & 18 & 100.00 & 3 & 100.00 \\
\hline
\end{tabular}

注: 为便于统计计算, 表中参与退出的农户总数为截至调研日期时的大约数。

的 $14.29 \%$; 退出换现金、换股份和换保障模式均有 现在或曾经是村干部的受访农户,其所占比例分别 为 $6.86 \% 、 7.69 \%$ 和 $28.57 \%$; 退出换现金、换股份模 式有超过一半的的受访农户都掌握除耕种以外的 其他劳动技能,退出换保障的受访农户都是建档立 卡户,掌握除耕种外其他技能的受访农户仅占其样 本总数的 $14.29 \%$ 。在受访者的家庭信息当中,退出 换现金、换股份模式的受访农户家庭人数都以 4 6 人为主, 退出换保障的受访农户家庭劳动力少且总 人数均少于 3 人, 3 种退出模式的受访农户家庭需要 抚养的人数多为 $1 \sim 2$ 人; 退出换现金模式的受访农 户家庭在退出前的年总收人以 3 万 6 万元为主, 退 出之后年总收人增加到以 6 万 10 万元为主, 年总支 出在退出前后都以 4 万 $~ 6$ 万元为主; 退出换股份模 式的受访农户家庭在退出前和退出后的年总收人 都以 6 万 10 万元为主, 年总支出在退出前以 4 万 $~ 6$ 万元为主, 退出后支出多大于 6 万元; 退出换保障模 式的受访农户家庭在退出前年总收人都少于 3 万 元, 退出后大部分农户年总收人均有所提升, 但年 总支出在退出前后变化不大, 以少于 2 万元为主; 3 种退出模式的受访农户家庭户主在退出前基本都 有养老保险, 实施农村土地承包经营权退出对其影 响不大。

农业经营组织的基本信息如表 4 所示, 在试点 退出换现金模式的龙门镇龙门村, 主要引进了 2 个 农业组织经营退出的土地。一个是经营永久退出 和长期退出土地的华杰种植农民专业合作社, 现有
约 $4 \mathrm{hm}^{2}$ 的土地规模, 主要经营类型为鱼、龙虾和柑 橘; 一个是大规模种植藤椒的专业大户, 主要经营 短期退出土地, 现经营规模约 $50 \mathrm{hm}^{2}$ 。在试点退出 换股份模式的永安镇大庄村、七里冲村和太平寺 村,引进的农业经营组织主要是发展农旅休闲项目 的川南大草原, 现经营土地约 $113 \mathrm{hm}^{2}$ 。在试点退出 换保障模式的永安镇下元村, 由于只有 12 户参与退 出, 退出面积 $2.53 \mathrm{hm}^{2}$ 且较为分散, 目前未引进农业 组织经营土地, 仍有 $0.67 \mathrm{hm}^{2}$ 退出的土地处于待利 用状态。

\section{3 结果及分析}

\section{1 单项绩效评价结果及分析}

\subsection{1 基于农户视角的“三换”模式绩效评价}

由表 5 可知,农户感知视角下不同农村土地承 包经营权退出模式的综合绩效呈现退出换股份模 式(24.97)>退出换现金模式(23.65)>退出换保障模 式(12.87) 的特点, 但从某一领域来看,一种农村土 地承包经营权退出模式带来的单一领域绩效不一 定同时优于另一种农村土地承包经营权退出模 式。就退出换现金模式而言,流程领域的绩效对综 合绩效的贡献最大, 同时优于退出换股份和换保障 模式,这说明退出换现金模式在实施过程当中有着 较为科学完备的退出流程, 是其他两种退出模式需 要优化改进的地方。就退出换股份模式来说,利益 相关者满意领域绩效对综合绩效的影响最大,但低 于退出换保障模式的利益相关者满意领域绩效值, 其能力领域绩效值同时高于退出换现金和换保障 


\section{表3 2018 年内江市市中区农村土地承包经营权退出农户基本信息}

Table 3 Basic information of farmers who have withdrawn from rural land contractual management rights in Central District of Neijiang City in 2018

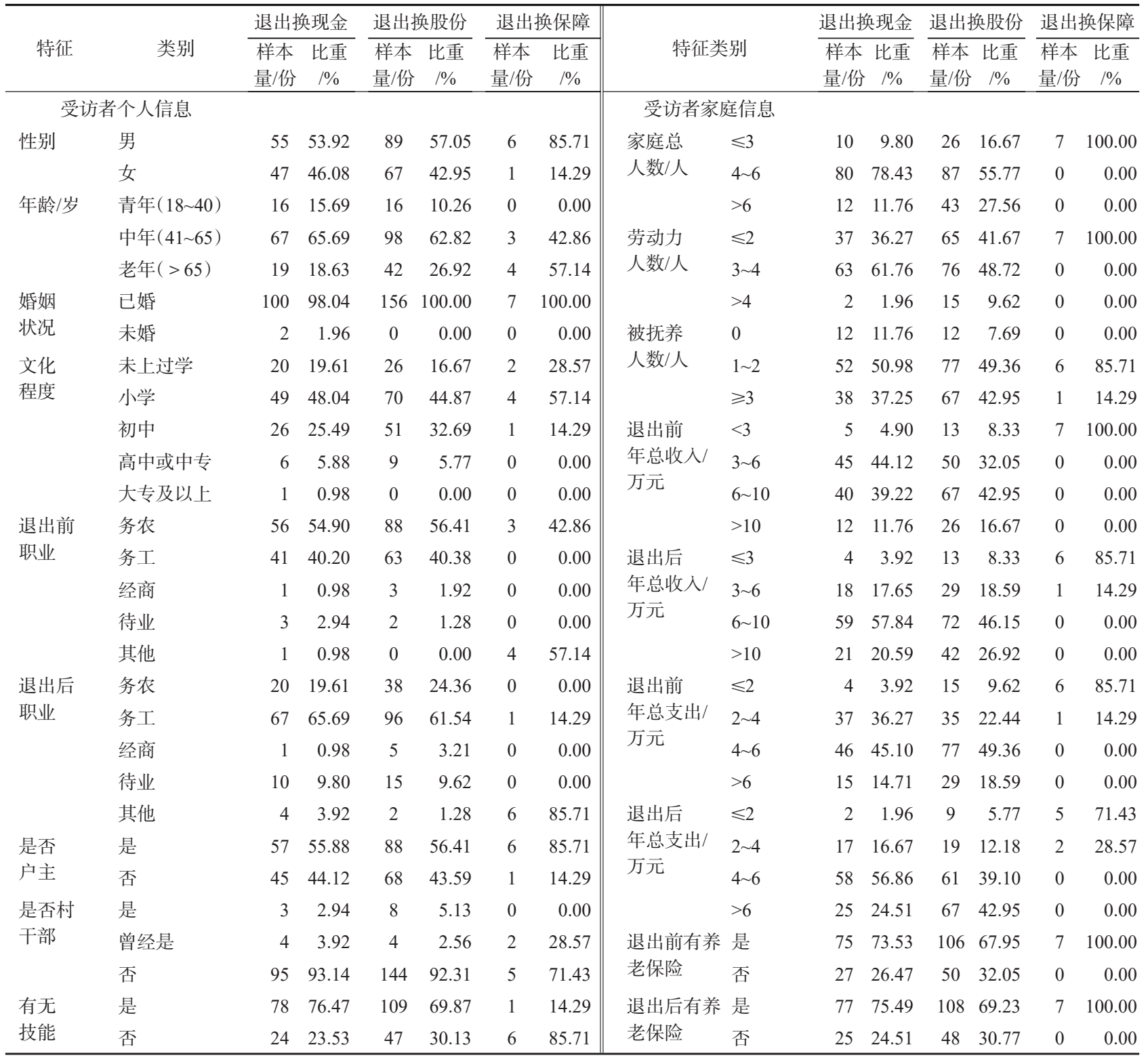

表4 2018 年内江市市中区农业经营组织基本信息

Table 4 Basic information of agricultural management organization in the Central District of Neijiang City in 2018

\begin{tabular}{|c|c|c|c|c|c|c|}
\hline 退出模式 & 试点村 & 农业经营组织 & 农业组织模式 & 退出形式 & 经营规模 $/ \mathrm{hm}^{2}$ & 主要经营类型 \\
\hline \multirow[t]{2}{*}{ 退出换现金 } & 龙门村 & 华杰种植农民专业合作社 & 农民专业合作社 & 永久退出、长期退出 & 4 & 鱼、龙虾、柑橘 \\
\hline & & 众和意农产品有限公司 & 专业大户 & 短期退出 & 50 & 藤椒 \\
\hline 退出换股份 & 大庄村、七里冲村、太平寺村 & 川南大草原 & 龙头企业 & 长期退出 & 113 & 农旅休闲项目 \\
\hline 退出换保障 & 下元村 & - & - & 永久退出 & 0.67 & 待利用 \\
\hline
\end{tabular}

注: 表中的经营规模数据为截至调研日期时的大约值。

模式。退出换股份模式的农户将承包地的使用权 人股农业经营组织,在拥有货币化股权的同时, 可 以持续分享承包地的增值收益,农户对此模式有较
高的满意度评价。就退出换保障模式而言,其利益 相关者满意、利益相关者贡献和战略领域绩效值均 高于退出换现金和换股份模式。对于大部分农户 
表 52018 年内江市市中区农户类“三换”模式绩效评价结果

Table 5 Performance evaluation results of the "three-change” model of farmers in Central District of Neijiang City in 2018

\begin{tabular}{|c|c|c|c|c|c|c|c|c|}
\hline \multirow{2}{*}{ 目标层 } & \multirow{2}{*}{ 准则层(权重) } & \multirow{2}{*}{ 指标层(权重) } & \multicolumn{2}{|c|}{ 退出换现金 } & \multicolumn{2}{|c|}{ 退出换股份 } & \multicolumn{2}{|c|}{ 退出换保障 } \\
\hline & & & 初始值 & 绩效值 & 初始值 & 绩效值 & 初始值 & 绩效值 \\
\hline \multirow{19}{*}{$\begin{array}{l}\text { 农村土 } \\
\text { 地承包 } \\
\text { 经营权 } \\
\text { 退出绩 } \\
\text { 效评价 } \\
A 1\end{array}$} & \multirow{3}{*}{$\begin{array}{l}\text { 利益相关者满意 } \\
B 1(0.0402)\end{array}$} & 农户退出土地承包经营权的意愿率 $C 1$ (0.006 1) & 75.49 & 0.46 & 67.31 & 0.41 & 85.71 & 0.52 \\
\hline & & 农户对该退出补偿标准的满意率 $C 2(0.5573)$ & 33.33 & 18.58 & 39.10 & 21.79 & 85.71 & 47.77 \\
\hline & & 农户对该退出模式的满意率 $C 3$ (0.436 6) & 40.20 & 17.55 & 69.87 & 30.51 & 85.71 & 37.42 \\
\hline & \multicolumn{2}{|c|}{ 利益相关者满意领域绩效 } & \multicolumn{2}{|c|}{36.59} & \multicolumn{2}{|c|}{52.71} & \multicolumn{2}{|c|}{85.71} \\
\hline & \multirow{2}{*}{$\begin{array}{l}\text { 利益相关者贡献 } \\
B 2(0.5059)\end{array}$} & 农户人均纯收人变化率 $C 8$ (0.191 2) & 2.88 & 0.55 & 8.77 & 1.68 & 6.69 & 1.28 \\
\hline & & 农户恩格尔系数变化率 $C 9$ (0.808 8) & 2.14 & 1.73 & 1.78 & 1.44 & 11.58 & 9.37 \\
\hline & \multicolumn{2}{|c|}{ 利益相关者贡献领域绩效 } & \multicolumn{2}{|c|}{2.28} & \multicolumn{2}{|c|}{3.12} & \multicolumn{2}{|c|}{10.65} \\
\hline & \multirow[t]{3}{*}{ 战略B3（0.038 2) } & 农户对退出政策的认识程度 $C 15$ (0.014 7) & 49.02 & 0.72 & 37.18 & 0.55 & 57.14 & 0.84 \\
\hline & & 农户对退出风险的判定 C16 (0.351 9) & 60.78 & 21.39 & 38.46 & 13.53 & 100.00 & 35.19 \\
\hline & & 土地承包经营权退出公众支持率 $C 17$ (0.633 4) & 39.22 & 24.84 & 51.28 & 32.48 & 28.57 & 18.10 \\
\hline & \multicolumn{2}{|l|}{ 战略领域绩效 } & \multicolumn{2}{|c|}{46.95} & \multicolumn{2}{|c|}{46.56} & \multicolumn{2}{|c|}{54.13} \\
\hline & \multirow[t]{3}{*}{ 能力 $B 4(0.2641)$} & 退出农户维护自身权利的水平 $C 23(0.1542)$ & 78.43 & 12.09 & 72.44 & 11.17 & 28.57 & 4.41 \\
\hline & & 退出农户风险规避能力 $C 24(0.6380)$ & 32.50 & 20.74 & 48.96 & 31.24 & 0.00 & 0.00 \\
\hline & & 退出农户接受职业培训的比率 C25（0.207 8) & 56.86 & 11.82 & 28.85 & 5.99 & 14.29 & 2.97 \\
\hline & \multicolumn{2}{|l|}{ 能力领域绩效 } & \multicolumn{2}{|c|}{44.65} & \multicolumn{2}{|c|}{48.40} & \multicolumn{2}{|c|}{7.38} \\
\hline & \multirow[t]{2}{*}{ 流程 B5（0.151 6) } & 农户对退出程序的认识程度 $C 30$ (0.001 5) & 87.25 & 0.13 & 67.31 & 0.10 & 100.00 & 0.15 \\
\hline & & 农户决策参与度 C31 (0.998 5) & 49.02 & 48.95 & 44.23 & 44.16 & 0.00 & 0.00 \\
\hline & \multicolumn{2}{|l|}{ 流程领域绩效 } & \multicolumn{2}{|c|}{49.08} & \multicolumn{2}{|c|}{44.26} & \multicolumn{2}{|c|}{0.15} \\
\hline & \multicolumn{2}{|c|}{ 农村土地承包经营权退出综合绩效 } & \multicolumn{2}{|c|}{23.65} & & 97 & & 87 \\
\hline
\end{tabular}

注: 初始值为通过绩效指标体系(表 1)中的计算公式求取的指标初始绩效值; 绩效值为指标初始值加权后的结果; 各领域绩效是其各指标 绩效值的简单相加;农村土地承包经营权退出综合绩效是对各项指标绩效值加权算术平均后的结果。

来说, 土地是他们生产生存的根本, 失去了土地意 味着失去了维持其生存和发展的屏障,退出换保障 能够为农户的基本生存提供强有力的保障。因此, 除了给付退地农户补偿金外,对那些以土地为生的 农户增加以土地换取养老和医疗保障的补偿办法 是今后退出换现金和换股份模式努力改进的方向。

3.1.2 基于农村集体经济组织视角的 “三换” 模式绩 效评价

基于农村集体经济组织视角的“三换”模式绩 效评价结果显示(表6),退出换现金模式(29.07)绩 效值最高,退出换股份模式 (23.38) 次之, 退出换保 障模式 (6.94) 最低。尽管从利益相关者满意、利益 相关者贡献、能力和流程领域来看, 退出换保障模 式绩效值均高于退出换现金和换股份模式,但战略 领域绩效对其综合绩效的贡献度最小。退出换保 障模式所在的下元村是永安镇 3 个省级贫困村之 一, 是一个比较典型的无资源、无资金、无产业的
“三无村”,在此背景下,土地承包经营权退出在除 战略领域外取得较高的绩效水平,一方面是村集体 努力的结果,另一方面与农户的配合以及当地政府 的支持息息相关。下元村在当地政府的支持下，组 建成立了集体经济股份合作社,在壮大村集体经济 的同时,通过“五股分配” (人头股、发展股、扶贫股、 土地股、管理股)的方式使农户集体受益,带动全村 农民脱贫致富。至于战略领域绩效不显著以及利 益相关者贡献领域土地撂荒面积变化率绩效为负 值, 是因为退出换保障模式所要求的退出对象必须 是全部丧失劳动能力的建档立卡户, 满足退出要求 的农户数少, 退出面积有限且较为分散, 难以实现 规模经营和充分有效利用。因此,在当地财政许可 的情况下, 适当降低退出换保障门槛, 鼓励更多农 户退出土地承包经营权, 是实现退出土地连片经 营,提高绩效水平的关键。对于退出换现金和换股 份模式来说,在充分尊重农户意愿的基础上,设置 
表 62018 年内江市市中区农村集体经济组织类“三换”模式绩效评价结果

Table 6 Performance evaluation results of the "three-change" model of rural collective economic organizations in Central District of Neijiang City in 2018

\begin{tabular}{|c|c|c|c|c|c|c|c|c|}
\hline \multirow{2}{*}{ 目标层 } & \multirow{2}{*}{ 准则层(权重) } & \multirow{2}{*}{ 指标层(权重) } & \multicolumn{2}{|c|}{ 退出换现金 } & \multicolumn{2}{|c|}{ 退出换股份 } & \multicolumn{2}{|c|}{ 退出换保障 } \\
\hline & & & 初始值 & 绩效值 & 初始值 & 绩效值 & 初始值 & 绩效值 \\
\hline \multirow{17}{*}{$\begin{array}{c}\text { 农村土 } \\
\text { 地承包 } \\
\text { 经营权 } \\
\text { 退出绩 } \\
\text { 效评价 } \\
A 1\end{array}$} & \multirow{2}{*}{$\begin{array}{l}\text { 利益相关者满意 } B 1 \\
(0.0141)\end{array}$} & 农户对退出工作的配合程度 C4 (0.446 3) & 49.02 & 21.88 & 51.92 & 23.17 & 57.14 & 25.50 \\
\hline & & 村集体负责员对退出工作的满意率 C5 (0.553 7) & 100.00 & 55.37 & 90.91 & 50.33 & 100.00 & 55.37 \\
\hline & \multicolumn{2}{|c|}{ 利益相关者满意领域绩效 } & \multicolumn{2}{|c|}{77.25} & \multicolumn{2}{|c|}{73.50} & \multicolumn{2}{|c|}{80.87} \\
\hline & \multirow{3}{*}{$\begin{array}{l}\text { 利益相关者贡献 } B 2 \\
(0.0385)\end{array}$} & 村集体收人变化率 C10（0.021 2） & 108.33 & 0.00 & 87.50 & 1.86 & 168.00 & 3.56 \\
\hline & & 村集体贫困人口变化率 $C 11 （ 0.9710 ）$ & 8.33 & 8.09 & 14.29 & 13.87 & 30.43 & 29.55 \\
\hline & & 土地撂荒面积变化率 C12（0.007 8） & 100.00 & 0.78 & 100.00 & 0.78 & -150.00 & -1.17 \\
\hline & \multicolumn{2}{|c|}{ 利益相关者贡献领域绩效 } & \multicolumn{2}{|c|}{8.87} & \multicolumn{2}{|c|}{16.51} & \multicolumn{2}{|c|}{31.94} \\
\hline & \multirow{2}{*}{ 战略 B3（0.481 3） } & 村集体土地规模经营实现率 $C 18$ (0.486 2) & 88.33 & 42.95 & 24.21 & 11.77 & 2.55 & 1.24 \\
\hline & & 退出农户产权纠纷变化率 C19（0.513 8) & 16.67 & 8.56 & 55.56 & 28.54 & 0.00 & 0.00 \\
\hline & \multicolumn{2}{|l|}{ 战略领域绩效 } & \multicolumn{2}{|c|}{51.51} & \multicolumn{2}{|c|}{40.31} & \multicolumn{2}{|c|}{1.24} \\
\hline & \multirow[t]{2}{*}{ 能力 $B 4(0.4582)$} & 退出补偿金拨付及时度 $C 26$ (0.020 6) & 100.00 & 2.06 & 98.72 & 2.04 & 100.00 & 2.06 \\
\hline & & 退出农户养老保险覆盖变化率 C27 (0.979 4) & 2.67 & 2.61 & 1.88 & 1.84 & 4.99 & 4.89 \\
\hline & \multicolumn{2}{|l|}{ 能力领域绩效 } & \multicolumn{2}{|c|}{4.67} & \multicolumn{2}{|c|}{3.88} & \multicolumn{2}{|c|}{6.95} \\
\hline & \multirow[t]{2}{*}{ 流程 $B 5$ (0.007 9) } & 退出程序合法性 C32（0.501 0) & 88.24 & 44.20 & 64.10 & 32.11 & 100.00 & 50.10 \\
\hline & & 退出过程公开性 C33（0.499 0） & 90.20 & 45.01 & 70.51 & 35.19 & 100.00 & 49.90 \\
\hline & \multicolumn{2}{|l|}{ 流程领域绩效 } & \multicolumn{2}{|c|}{89.21} & \multicolumn{2}{|c|}{67.30} & \multicolumn{2}{|c|}{100.00} \\
\hline & \multicolumn{2}{|c|}{ 农村土地承包经营权退出综合绩效 } & \multicolumn{2}{|c|}{29.07} & \multicolumn{2}{|c|}{23.38} & & \\
\hline
\end{tabular}

适当的退出门槛, 实施严格的退出程序, 提高退出 过程的公开度,大力发展村集体经济是今后模式优 化的重点。

3.1.3 基于农业经营组织视角的退出换现金和换股 份模式绩效评价

由表 7 的绩效评价结果可知, 基于农业经营组 织视角的退出换股份模式绩效 (94.27) 最佳, 退出换 现金模式(32.15)较差。从某一领域来看, 不同农村 土地承包经营权退出模式的单一领域绩效存在差 异。在利益相关者满意、战略和流程领域, 退出换 现金模式绩效值均高于退出换股份模式。在试点 退出换现金模式的龙门镇龙门村,存在永久、长期 和短期 3 种退出形式, 农户可根据自身意愿及家庭 资源禀赋自由选择退出形式, 退出的农户数较多且 土地集中, 利于农业经营组织实现规模化经营。制 定多种退出形式, 满足农户的多样化需求是退出换 股份模式优化的重点。在利益相关者贡献和能力 领域,退出换股份模式绩效值遥遥领先于退出换现 金模式。对于经营退出换股份土地的农业经营组 织 (川南大草原) 来说, 在土地规模扩大的同时, 在
单位土地面积上合理增加机械、劳动和科技等生产 要素的投人是提高单位土地产出的关键。由此可 见，在遵从“土地报酬递减规律”的前提下,在投人 达到最佳点之前，持续的投资是实现土地集约利 用,农业经营组织产出最大化的重要举措, 这是值 得经营退出换现金土地的农业组织学习借鉴的地方。

\section{2 基于综合视角的绩效评价结果及分析}

目前, 参与退出换保障模式的退出农户数少、 退出面积有限且分散,该村尚未引进农业经营组织 对退出土地进行规模化经营。因此,本文仅对调研 时获取的退出换现金和换股份模式的数据进行统 计分析,各指标取值及计算结果如表 8 所示。从农 户、农村集体经济组织和农业经营组织的综合视角 出发,研究区农村土地承包经营权退出换股份模式 的综合绩效最佳,绩效值为 62.07 ,退出换现金模式 的综合绩效欠佳,绩效分值为 38.42 。就退出换股份 模式而言, 准则层各领域的绩效分值呈现能力领域 (116.41) > 利益相关者满意领域 (67.14) > 利益相关 者贡献领域 (64.15)>流程领域 (40.92)>战略领域 (32.12) 的特点。能力领域绩效对退出换股份模式 
表 72018 年内江市市中区农业经营组织退出换现金和换股份模式绩效评价结果

Table 7 Performance evaluation results of agricultural operation organizations withdrawing from cash exchange and stock exchange model in Central Ddistrict of Neijiang city in 2018

\begin{tabular}{|c|c|c|c|c|c|c|}
\hline \multirow{2}{*}{ 目标层 } & \multirow{2}{*}{ 准则层(权重) } & \multirow{2}{*}{ 指标层(权重) } & \multicolumn{2}{|c|}{ 退出换现金 } & \multicolumn{2}{|c|}{ 退出换股份 } \\
\hline & & & 初始值 & 绩效值 & 初始值 & 绩效值 \\
\hline 农村土地 & 利益相关者满意 $B 1$ & 农业组织规模经营目标的实现率 C6 (0.525 4) & 80.00 & 42.03 & 68.00 & 35.73 \\
\hline 承包经营 & $(0.1657)$ & 农业组织对退出工作的满意率 $C 7$ (0.474 6) & 100.00 & 47.46 & 100.00 & 47.46 \\
\hline 权退出绩 & \multicolumn{2}{|l|}{ 利益相关者满意领域绩效 } & \multicolumn{2}{|c|}{89.49} & \multicolumn{2}{|c|}{83.19} \\
\hline \multirow[t]{13}{*}{ 效评价 $A 1$} & 利益相关者贡献 $B 2$ & 单位土地产出变化率 $C 13$ (0.996 7) & 10.13 & 10.09 & 253.00 & 252.17 \\
\hline & $(0.0418)$ & 单位土地机械使用变化率 C14 (0.003 3) & 10.69 & 0.04 & 70.00 & 0.23 \\
\hline & \multicolumn{2}{|l|}{ 利益相关者贡献领域绩效 } & \multicolumn{2}{|c|}{10.13} & \multicolumn{2}{|c|}{252.40} \\
\hline & \multirow[t]{3}{*}{ 战略B3（0.236 7) } & 政府投人资金占退出补偿金的比重 $C 20$ (0.727 5) & 70.09 & 50.99 & 0.00 & 0.00 \\
\hline & & 单位土地劳动力投人变化率 $C 21 （ 0.2718 ）$ & 13.58 & 3.69 & 17.67 & 4.80 \\
\hline & & 单位土地科技投人变化率 $C 22$ (0.000 7) & 10.24 & 0.01 & 66.67 & 0.05 \\
\hline & \multirow[t]{2}{*}{ 能力 $B 4(0.2114)$} & 单位土地农业组织利润变化率 $C 28$ (0.461 0) & 9.80 & 4.52 & 700.00 & 322.70 \\
\hline & & 退出补偿金占农业组织利润的比重 $C 29$ (0.539 0) & 10.67 & 5.75 & 5.00 & 2.69 \\
\hline & \multicolumn{2}{|l|}{ 能力领域绩效 } & \multicolumn{2}{|c|}{10.27} & \multicolumn{2}{|c|}{325.39} \\
\hline & \multirow[t]{2}{*}{ 流程 $B 5(0.3444)$} & 农户生产过程参与度 C34 (0.500 0) & 0.00 & 0.00 & 0.00 & 0.00 \\
\hline & & 信息共享度 C35（0.500 0） & 10.34 & 5.17 & 0.00 & 0.00 \\
\hline & \multicolumn{2}{|l|}{ 流程领域绩效 } & \multicolumn{2}{|c|}{5.17} & \multicolumn{2}{|c|}{0.00} \\
\hline & \multicolumn{2}{|c|}{ 农村土地承包经营权退出综合绩效 } & \multicolumn{2}{|c|}{32.15} & \multicolumn{2}{|c|}{94.27} \\
\hline
\end{tabular}

综合绩效影响最大, 战略领域绩效最差。退出换现 金模式的准则层各领域绩效分值呈现利益相关者 满意领域 (66.89)>战略领域 (57.62)>流程领域 (52.86)>能力领域 (24.94)>利益相关者贡献领域 (23.87) 的特点。利益相关者满意领域绩效对退出 换现金模式综合绩效影响最大,利益相关者贡献领 域绩效最差。在遵从“土地报酬递减规律”前提下， 在投人达到最佳点之前, 合理追加投资是经营退出 换现金土地的农业组织需要学习借鉴的地方; 充分 考虑农户自身禀赋的差异性,制定多种退出形式, 满足农户多样化需求,退出前进行广泛的政策宣 传, 退出中提高农户决策参与度与退出过程公开 度, 是今后退出换股份模式优化的重点。

\section{4 结论与讨论}

\section{1 结论}

（1）基于利益相关者视角构建的绩效三棱柱评 价模型适用于内江市市中区农村土地承包经营权 退出绩效评价。其单项绩效评价信息能够深人挖 掘研究区农村土地承包经营权退出的利益相关者
（农户、农村集体经济组织和农业经营组织）分别在 退出前决策、退出中效率和退出后效果方面存在的 问题与不足,为区域优化退出模式提供理论依据; 其综合绩效评价信息能够综合反映何种退出模式 的实施效果最佳, 为其他试验区选择退出模式提供 实践支撑。

(2) 不同退出模式的单项绩效水平和综合绩效 水平具有显著的差异性。从农户视角出发, 3 种退 出模式的综合绩效由大到小依次为: 退出换股份模 式 (24.97), 退出换现金模式 (23.65), 退出换保障模 式(12.87), 这说明农户感知视角下的退出换股份模 式比较适合自身家庭禀赋条件; 从农村集体经济组 织视角出发, 3 种退出模式的绩效水平呈现退出换 现金模式(29.07)>退出换股份模式(23.38)>退出换 保障模式 (6.94)的特点, 由此可以说明退出换现金 模式较好地满足了农村集体经济组织的利益诉求, 且在实施的过程当中取得了较好的行为绩效; 从农 业经营组织视角出发,退出换股份模式(94.27)的绩 效水平遥遥领先于退出换现金模式(32.15), 由此可 


\section{表 82018 年内江市市中区退出换现金、换股份模式综合绩效评价结果}

Table 8 Comprehensive performance evaluation results of exiting cash exchange and stock exchange model in Central District of Neijiang City in 2018

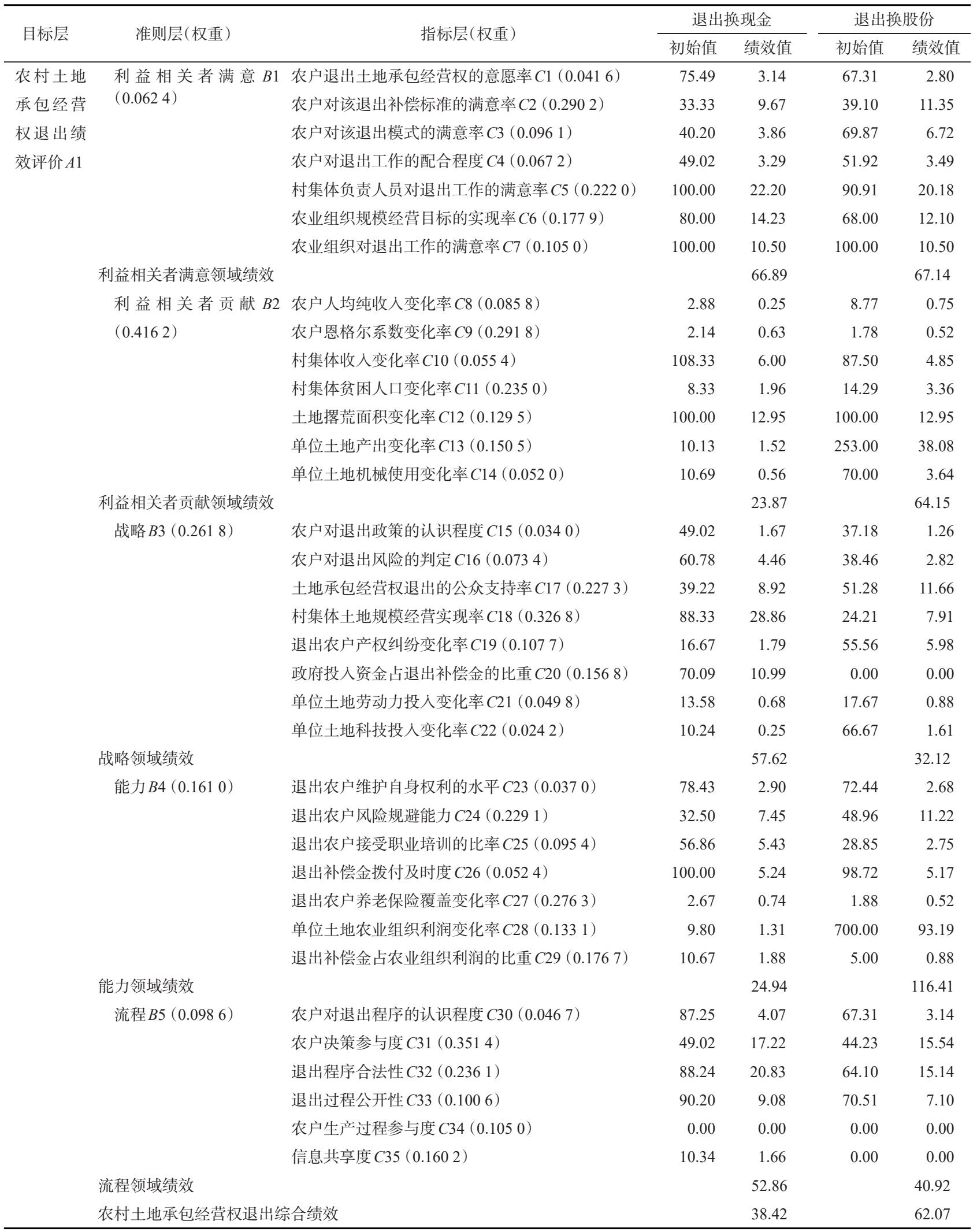


见,经营退出换股份土地的农业组织较好地实现了 单位土地产出最大化的战略目标, 实现了土地的高 效集约利用; 从农户、农村集体经济组织和农业经 营组织的综合视角出发,退出换股份模式 (62.07)绩 效最佳,退出换现金模式 (38.42) 次之, 由此可以表 明,相较于退出换现金模式而言, 退出换股份模式 在退出全过程中实施效果最好。

(3) 依据不同退出模式绩效水平差异, 可在相 互借鉴的基础上,基于利益相关者视角分别对 3 种 退出模式进行逐步优化。第一, 加强技能培训, 提 高就业或再就业能力是 3 种退出模式的农户着力提 升的方面。退出农户应该积极参与夜校培训, 通过 培训获得力所能及的工作技能从而实现就业或再 就业, 提高其就业竞争力与融人社会的能力; 第二, 农村集体经济组织充分考虑农户自身禀赋的差异 性, 制定多种退出形式, 满足农户的多样化需求是 退出换股份和换保障模式重点考虑的方面。对于 以土地为生的农户除了给予现金补偿外, 以土地换 取养老和医疗保障的办法是退出换现金和换股份 模式努力改进的方向。另外，设置适当的退出门 槛, 实施严格的退出程序, 提高退出过程公开度以 及大力发展村集体经济是退出换现金和换股份模 式优化的重点; 第三, 对于农业经营组织而言, 在遵 从“土地报酬递减规律” 的前提下,在投人达到最佳 点之前, 持续的生产要素投人是实现土地集约利用 和土地产出最大化的前提条件, 这是退出换现金模 式需要学习借鉴的地方。

\section{2 讨论}

(1) 土地承包经营权退出模式的不同是其单项 绩效和综合绩效水平具有显著差异性的重要因素, 同时农户的资源禀赋、思想观念, 农村集体经济组 织的经济实力、行为能力以及农业组织的经营类 型、战略决策等因素也影响着绩效水平。所以,在 综合考虑相关主体差异因素的基础上选择适合的 农村土地承包经营权退出模式是实现利益相关者 效益最大化, 增进社会总福利的关键。因此, 基于 退出模式,农户的资源禀赋、思想观念, 农村集体经 济组织的经济实力、行为能力, 农业组织的经营类 型、战略决策等多因素开展农村土地承包经营权退 出绩效影响机理研究将成为该领域的重要研究内容。
(2) 目前承担农村土地承包经营权退出试点任 务的有重庆市梁平县、四川省成都市、四川省内江 市市中区和贵州省遵义市湄潭县等。本文仅以内 江市市中区为例进行实证研究,研究区域有待拓展 以增强研究结论的可靠性和适用性。此外,在试点 区域不断拓展的基础上,后期还应开展试验区农村 土地承包经营权退出时空差异化绩效评价及农村 土地承包经营权退出(退出前-退出中-退出后)风 险评估、风险识别和风险防范机制等方面的研究。

\section{参考文献(References):}

[1] 文枫, 鲁春阳, 杨庆媛, 等. 农村集体建设用地流转研究进展[J]. 地理科学进展, 2011, 30(9): 1193-1200. [Wen F, Lu C Y, Yang Q Y, et al. Progress in research on rural collective construction land transfer[J]. Progress in Geography, 2011, 30(9): 1193-1200.]

[2]四川省人民政府. 我省四地纳人全国第二批农村改革试验 [EB/ OL]. (2014-12-08)[2018-11]. http: //www.sc.gov.cn/10462/10464/ 10797/2014/12/8/10320397.shtml. [Sichuan Provincial People's Government. Four Provinces in Our Province Have Been Included in the Second Batch of Rural Reform Experiments in the Country [EB/OL]. (2014- 12- 08) [2018-11]. http: //www.sc.gov.cn/10462/ 10464/10797/2014/12/8/10320397.shtml.]

[3] 陈永昌. 全面学习解读国务院《关于转变农业发展方式的意见》 [J]. 农场经济管理, 2015, (11): 3-3. [Chen Y C. A comprehensive study of the state council's "opinions on transforming agricultural development modes" [J]. Farm Economic Management, 2015, (11): 3-3.]

[4] 王雯慧. 国务院关于印发全国农业现代化规划(2016-2020年) 的通知-为未来五年农业发展指路[J]. 中国农村科技, 2016, (11): 7-7. [Wang W H. Notice of the state council on printing and distributing the national agricultural modernization plan (20162020)-instructing the development of agriculture in the next five years[J]. China Rural Science and Technology, 2016, (11): 7-7.]

[5] 钟涨宝, 聂建亮. 建立健全农村土地承包经营权退出机制初探 [J]. 理论与改革, 2010, (5): 78-80. [Zhong Z B, Nie J L. Study on establishing and perfecting the exit mechanism of rural land contract management right[J]. Theory and Reform, 2010, (5): 78-80.]

[6] 魏亚男, 宋帅官. 完善农村土地承包经营权退出机制[J]. 农业经 济, 2014, (5): 16-18. [Wei Y N, Song S G. Improving the exit mechanism of rural land contractual management rights[J]. Agricultural Economy, 2014, (5): 16-18.]

[7] 王建友. 完善农户农村土地承包经营权的退出机制[J]. 农业经 济与管理, 2011, (3): 47-53. [Wang J Y. Improving the exit mechanism of farmers' rural land contract management right[J]. Agricul- 
tural Economics and Management, 2011, (3): 47-53.]

[8] 吴兴国. 农村土地承包关系退出法律问题初探[J]. 求索, 2012, (2): 159-161. [Wu X G. A preliminary study on the legal issue of the withdrawal of rural land contract relationship[J]. Seeking, 2012, (2): 159-161.]

[9] 裴丽平. 我国农村土地承包经营权退出机制的完善[J]. 淮海工. 学院学报(人文社会版), 2017, 15(6): 26-29. [Pei L P. Improvement of the exit mechanism of rural land contract management right in China[J]. Journal of Huaihai Institute of Technology(Humanities and Social Sciences), 2017, 15(6): 26-29.]

[10] 童涁. 土地承包经营权退出机制的法律困境和制度建构[J]. 农 村经济, 2017, (2): 38-45.[Tong B. Legal dilemma and system construction of the exit mechanism of land contract management right [J]. Rural Economy, 2017, (2): 38-45.]

[11] 钟涨宝, 汪萍. 农地流转过程中的农户行为分析-湖北、浙江等 地的农户问卷调查[J]. 中国农村观察, 2003, (6): 55-64.[Zhong Z B, Wang P. Analysis of farmers' behavior in the process of farmland transfer-A survey of farmers in Hubei and Zhejiang[J]. China Rural Survey, 2003, (6): 55-64.]

[12] 高强, 宋洪远. 农村土地承包经营权退出机制研究[J]. 南京农业 大学学报(社会科学版), 2017, 17(4): 74-84. [Gao Q, Song H Y. Research on the exit mechanism of rural land contract management right[J]. Journal of Nanjing Agricultural University, Social Science Edition, 2017, 17(4): 74-84.]

[13] 王丽双, 王春平. 实现农地承包经营权退出制度的路径选择[J]. 学术交流, 2015, (11): 155-159. [Wang L S, Wang C P. Path choice of realizing the exit system of agricultural land contract management right[J]. Academic Exchange, 2015, (11): 155-159.]

[14] 方志权.农村土地承包经营权退出意愿调查-基于上海四区 1255 份农村调查问卷的分析[J]. 科学发展, 2017, (8): 37-43.

[Fang Z Q. Investigation on the exiting will of rural land contract management right-Based on the analysis of 1255 rural survey questionnaires in Shanghai four districts [J]. Science Development, 2017, (8): 37-43.]

[15] 张学敏. 离农分化、效用差序与承包地退出-基于豫、湘、渝 886 户农户调查的实证分析[J]. 农业技术经济, 2013, (5): 44-52. [Zhang X M. Departure from agriculture, utility difference and contractual exit-An empirical analysis based on survey of 886 households in Henan, Hunan and Guizhou[J]. Agricultural Technology \& Economy, 2013, (5): 44-52.]

[16] 王丽双, 王春平, 孙占祥. 农户分化对农地承包经营权退出意愿 的影响研究[J]. 中国土地科学, 2015, 29(9): 27-33. [Wang L S, Wang C P, Sun Z X. Research on the influence of farmers' differentiation on the willingness to exit the farmland contract management right[J]. China Land Science, 2015, 29(9): 27-33.]

[17] 刘同山. 农业机械化、非农就业与农民的承包地退出意愿[J]. 中 国人口·资源与环境, 2016, 26(6): 62-68. [Liu T S. Agricultural mechanization, non-agricultural employment and farmers' willing- ness to exit from contracted areas[J]. China Population, Resources and Environment, 2016, 26(6): 62-68.]

[18] 程飞.不同农村土地流转模式绩效评价研究 $[D]$. 重庆: 西南大 学, 2014. [Cheng F. Study on Performance Evaluation of Different Rural Land Transfer Models[D]. Chongqing: Southwest University, 2014.]

[19] 周菁. 成都市温江区农村集体土地流转绩效评价[D]. 雅安: 四 川农业大学, 2015. [Zhou J. Evaluation of Rural Collective Land Transfer Performance in Wenjiang District of Chengdu City[D]. Ya’an: Sichuan Agricultural University, 2015.]

[20] 王雅瑜. 晋江市英林镇农村土地流转模式绩效评价[D]. 福州: 福建农林大学, 2016. [Wang Y Y. Performance Evaluation of Rural Land Transfer Model in Yinglin Town, Jinjiang City[D]. Fuzhou: Fujian Agriculture and Forestry University, 2016.]

[21] 许亚敏. 基于可持续发展的农村土地流转综合绩效评价模型 [J]. 济宁学院学报, 2014, 35(1): 102-106. [Xu Y M. Comprehensive performance evaluation model of rural land transfer based on sustainable development[J]. Journal of Jining University, 2014, 35 (1): 102-106.]

[22] 王立敏. 滩坊市农地流转中介组织运行绩效研究[D]. 杨凌: 西 北农林科技大学, 2016. [Wang L M. Research on the Performance of Agricultural Land Transfer Intermediary Organizations in Weifang City[D]. Yangling: Northwest A\&F University, 2016.]

[23] 李文彦. 贵州省农村集体土地征收绩效评价研究[D]. 贵阳: 贵 州大学, 2016. [Li W Y. Research on Performance Evaluation of Rural Collective Land Collection in Guizhou Province[D]. Guiyang: Guizhou University, 2016.]

[24] 贾艳红, 赵军, 南忠仁, 等. 基于熵权法的草原生态安全评价一 以甘肃牧区为例 [J]. 生态学杂志, 2006, 25(8): 1003-1008. [Jia Y H, Zhao J, Nan Z R, et al. Evaluation of grassland ecological security based on entropy weight method-A case study of Gansu Pastoral Area[J]. Journal of Ecology, 2006, 25(8): 1003-1008.]

[25] 倪九派, 李萍, 魏朝富, 等. 基于 AHP 和商权法赋权的区域土地 开发整理潜力评价[J]. 农业工程学报, 2009, 25(5): 202-209. [Ni J P, Li P, Wei C F, et al. Evaluation of regional land development and consolidation potential based on AHP and entropy weight method[J]. Transactions of the Chinese Society of Agricultural Engineering, 2009, 25(5): 202-209.]

[26] 李萍,魏朝富, 邱道持. 基于熵权法赋权的区域耕地整理潜力评 价[J]. 中国农学通报, 2007, 23(6): 536-541.[Li P, Wei C F, Qiu D C. Evaluation of regional cultivated land consolidation potential based on entropy weight method[J]. Chinese Agricultural Science Bulletin, 2007, 23(6): 536-541.]

[27] 於由, 黄贤金, 钟太洋. 省级政府土地管理绩效督察评价指标体 系研究[J]. 中国土地科学, 2014, 28(9): 17-24. [Yu R, Huang X J, Zhong T Y. Study on the evaluation index system of provincial government land management performance supervision[J]. China Land Science, 2014, 28(9): 17-24.] 


\title{
Performance evaluation of rural land contract management right exit in Central District of Neijiang City from the perspective of stakeholders
}

\author{
NIU Haipeng ${ }^{1,2}$, LI Congcong ${ }^{1}$ \\ (1. School of Surveying and Land Information Engineering of Henan Polytechnic University, Jiaozuo 454000, China; \\ 2. The Research Centre of Land Economy and Urban-rural Development of Henan Polytechnic University, Jiaozuo 454000, China)
}

\begin{abstract}
The performance of rural land contractual management right exit is a comprehensive representation of the core stakeholders (farmers, rural collective economic organizations, and agricultural management organizations) in the decision- making. Before withdrawal, behavioral efficiency during exit and the effect after exit, it is to reflect the effectiveness of the implementation of the exit policy for rural land contractual management rights. Based on the perspective of stakeholders, this paper constructs a triangular prism evaluation model for the performance of rural land contractual management right exit and uses the comprehensive index method to scientifically evaluate single performance and overall performance of the rural land contractual management right of Neijiang City Central District to withdraw cash, exchange shares, and change the security model. The results show that: (1) The performance based triangular prism evaluation model and based on the stakeholder perspective is applicable to the performance evaluation of rural land contract management right exit. Its individual performance and comprehensive performance can reflect the effectiveness and deficiency of the land contractual management right exit. (2) The single performance level and the comprehensive performance level of the different exit mode exhibits significant differences. In addition to the performance value of the rural collective economic organization, the exit value is higher than the exit-for-share model. Other perspectives (farmers and agricultural management organizations) and overall performance values are lower than the exit- for- share model. The exit- for-guarantee model has the worst performance. (3) According to the differences of performance levels of different exit modes, it is of great significance to learn from the basis of mutual learning and to optimize the ideal optimization plan for the orderly exit of rural land contractual management rights.
\end{abstract}

Key words: rural; land contractual management right; stakeholder; exit performance; performance triangular prism model; Neijiang City 